Галаган В. I., к.військ.н., доцент (ORCID: 0000-0001-9578-0895);

Полішко С. В. к.т.н., с.н.c. $\quad$ (ORCID: 0000-0002-2172-7618);

Бондарчук С. В.

(ORCID: 0000-0003-0624-9782)

Центр воєнно-стратегічних досліджень Національного університету оборони України імені Івана Черняховського, Київ

\title{
Формування вимог до інформаційно-аналітичного автоматизованого робочого місця керівного складу за напрямом управління нерухомим військовим майном Збройних Сил України
}

Резюме. Стаття присвячена питанням формування та обгрунтування вимог до побудови інформаційно-аналітичного автоматизованого робочого місця керівного складу за напрямом управління нерухомим військовим майном, як однієї з найважливіших складових життєвого циклу інформаційних систем, що використовуються у повсякденній діяльності організацій (структур) Збройних Сил України.

Ключові слова: інформаційно-аналітичне автоматизоване робоче місце; автоматизоване робоче місце керівного складу; управління нерухомим військовим майном.

Постановка проблеми. У Збройних Силах України успішно розробляються та впроваджуються різноманітні проекти інформатизації, які спрямовані на підвищення ефективності та поліпшення якості управління процесами повсякденної та бойової діяльності військ [1].

Життєвий цикл кожної інформаційної системи розпочинається із задуму про іiі створення, потім вона проходить етапи проектування, впровадження, випробовувань і використання. Закінчується життєвий цикл виводом системи 3 використання (зняттям 3 виробництва) через причини морального або фізичного старіння. Для інформаційних систем передбачено вісім стадій її створення та експлуатації [2]:

формування вимог до автоматизованої системи;

розроблення концепції системи;

розроблення технічного завдання для

проектування;

ескізне проектування;

технічне проектування;

виготовлення робочої документації;

введення в експлуатацію;

супроводження системи.

Базовою основою для успішного розроблення та впровадження програмних продуктів $\epsilon$ процес формування вимог до автоматизованої системи.

Ступінь розробленості проблеми. На сьогодні здійснюється розроблення автоматизованого інформаційно-аналітичного робочого місця керівного складу (IA APM), яке може стати одним 3 елементів системи підтримки прийняття рішень і певною мірою забезпечити етап інформаційної підготовки управлінського рішення.

Нині керівний склад 3С України, який безпосередньо здійснює управління нерухомим військовим майном не має повноцінного функціонального інформаційно-аналітичного автоматизованого робочого місця, яке задовольнить їх потреби під час прийняття обгрунтованих рішень. Отже, розроблення IA APM є одним із першочергових завдань у сфері управління нерухомістю, яке висувається керівним складом Міністерства оборони України та безпосередньо пов'язане зі створенням інформаційної системи управління оборонними ресурсами Defence Resource Management Information System (DRMIS).

Для адекватної та достовірної роботи IA APM на початковому етапі його розроблення необхідно провести детальне формування вимог, які повною мірою реалізують його функціональність та надалі забезпечать командира (начальника) необхідною інформацією для прийняття обгрунтованих рішень.

Зважаючи на викладене, метою статті $\epsilon$ формування та обгрунтування вимог до побудови IA АРМ як однієї з найважливіших складових життєвого циклу інформаційних систем, що використовуються у повсякденній діяльності організацій (структур) 3С України.

Виклад основного матеріалу. Формування вимог до IA АРM, що створюється, є одним 3 важливих завдань на 
початкових етапах розроблення програмного продукту. Вимоги - це можливості або умови, яким має відповідати розробка. Основне завдання етапу визначення вимог полягає в знаходженні того, що дійсно потрібно у формі, зрозумілій як замовнику, так i розробникові.

Зважаючи на характер і зміст Воєнної доктрини України, поглядів на застосування 3С України, стратегічного курсу України на євроінтеграцію і військове співробітництво, аналізу світового досвіду управління нерухомим військовим майном та положень квартирно-експлуатаційного забезпечення, загальні вимоги до IA АРM управління нерухомим військовим майном можуть бути структуровані таким чином:

1. Вимоги загального призначення $\underline{I A A P M}$. IA АРM керівного складу за напрямом управління нерухомим військовим майном має забезпечувати:

керівництво Міністерства оборони України, Генерального штабу ЗС України, інші органи військового управління достовірною інформацією, необхідною для прийняття управлінських рішень за напрямом управління нерухомим військовим майном;

оперативність, прозорість, відкритість квартирно-експлуатаційного забезпечення військ (сил) і сприяння прийняттю рішення командира (начальника) щодо оптимізації процесів планування, розподілу та використання ресурсів;

розмежування функцій органів управління квартирно-експлуатаційним забезпеченням військ (сил) на кожному рівні ієрархії на основі ранжирування задач управління;

розподіл функцій та повноважень в органах управління, що відповідають за організацію та здійснення квартирноексплуатаційного забезпечення відповідно до їх штатної структури і чисельності;

високу готовність системи квартирноексплуатаційного забезпечення військ (сил) до виконання завдань у воєнний час (оргструктури системи управління квартирноексплуатаційним забезпеченням військ (сил) у мирний $\mathrm{i}$ воєнний час мають бути максимально наближені одна до одної).

2. Вимоги до організачійної структури IA APM. IA APM керівного складу за напрямом управління нерухомим військовим майном має:

функціонувати на всіх рівнях військового управління 3 відповідними ступенями взаємодії; відповідати структурі, цілям, функціям, завданням i критеріям діяльності органів військового управління за напрямами управління нерухомим військовим майном;

забезпечувати інтеграцію процесів управління нерухомим військовим майном відповідно до рівня органу управління та повноважень посадових осіб;

забезпечувати інформаційну підтримку прийняття рішення посадовими особами за напрямом управління нерухомим військовим майном, 3 встановленими можливими технічними перервами, що не впливають на працездатність і можливість якісно виконувати завдання користувачів;

надавати відповідні функції для аналізу, контролю, обміну інформацією, цілісності баз даних та уникнення дублювання.

Основним постачальником інформації може бути підсистема управління нерухомим майном "Майно" Єдиної системи управління адміністративно-господарськими процесами ЗС України та інші підсистеми інформаційної системи управління оборонними ресурсами (DRMIS).

3. Вимоги до функиіональності IA APM. За основними функціональними властивостями IA APM має відповідати таким вимогам:

забезпечення повноти, достовірності, точності, актуальності, своєчасності, захищеності інформації, ергономічності іiі сприйняття;

підвищення якості та загальної ефективності виконання управлінських завдань, обгрунтованості та якості розроблених рішень щодо управління нерухомим військовим майном, скорочення часу на їх прийняття;

надання можливості візуалізації та відслідковування процесів управління нерухомим військовим майном;

забезпечення процесів підготовки персоналу.

4. Вимоги до технологічних властивостей IA АPM:

реалізація розробки має здійснюватися на основі уніфікованої програмно-технічної платформи розробки та функціонування спеціального програмного забезпечення;

створюватися згідно 3 концепцією відкритих систем 3 можливістю розвитку та модернізації завдяки введенню нових функціональних модулів, розширення функцій раніше створених, підключення нових інформаційних ресурсів і розширення кола користувачів; мати можливості гнучкого 
доналаштування програмного забезпечення, набуття нових функціональних спроможностей, удосконалення наявних процесів, виправлення недоліків, які виявлені під час практичного використання.

\section{5. Перелік складових IA APM,} призначення. IA АРМ має включати такі основні компоненти:

персональний

комп'ютер

встановленою операційною системою; комплекс програм для обробки інформації про об'єкти нерухомого військового майна;

базу інформаційного забезпечення (стандарти документів і уніфікованих форм, стандарти представлення показників, класифікатори та довідкова інформація);

навчальну систему (систему документації для користувача; інтегровану систему підказок; систему закладок, покажчиків і довідок; систему прикладів; систему контролю і виявлення помилок);

засоби налаштування АРМ (алгоритмів розрахунків, аналітичних i технологічних параметрів; пристроїв: принтера, сканера, модему; ергономіки екранних форм тощо);

засоби експлуатації

APM

(класифікатори, генератор звітних форм, інструментарій прийому та передачі даних по каналах 3в'язку, копіювання i збереження даних, адміністратор баз даних, моніторинг роботи конкретних користувачів).

Крім цього, АРМ комплектується документацією i методичними матеріалами щодо застосування програм та регламентами виконання робіт щодо обробки інформації.

Для ефективного відпрацювання технологічних рішень щодо управління нерухомим військовим майном IA APM поділяється на тестове та продуктивне середовище у вигляді двох територіально рознесених серверів.

6. Система класифікаиї та кодування має становити собою сукупність державних i галузевих класифікаторів, які охоплюють усі напрями діяльності органів управління, необхідних для функціонування IA APM управління нерухомим військовим майном ЗС України та правил їх ведення. Система має включати класифікатори на всіх ієрархічних рівнях:

загальносистемні - єдині в рамках системи управління нерухомим військовим майном 3С України класифікатори, необхідні для розв'язання загальних задач за допомогою моделей, які використовують дані інших підсистем (основною $є$ ЄСУ АГП ЗС
України); загальнодержавні та галузеві класифікатори МО України та інших силових міністерств і відомств;

системні - єдині у межах конкретної підсистеми управління нерухомим військовим майном 3С України класифікатори, що забезпечують функціонування математичних моделей для розв'язання інформаційних i розрахункових задач та обмін інформацією між складовими;

локальні - класифікатори, необхідні для розв'язання часткових задач.

7. Вимоги до інформачійного обміну. Інформаційна-аналітична база для функціонування IA APM має формуватися у межах організації єдиного інформаційного простору 3 використанням сучасних інформаційно-телекомунікаційних мереж 3С України за розробленою технологією обміну, яка відповідає вимогам забезпечення безпеки інформації. Інформаційна сумісність баз даних щодо управління нерухомим військовим майном 3С України має забезпечуватися за допомогою погодження складу, структури, змісту i обсягів інформації взаємообміну, застосуванням однорідних чинників, єдиних процедур формування та оновлення баз даних, єдиної системи класифікації та кодування інформації, єдиної уніфікованої системи документів.

8. Технологічні вимоги до IA APM. IA APM керівного складу за напрямом управління нерухомим військовим майном ЗС України має бути:

самостійною інформаційно-аналітичною підсистемою управління нерухомим військовим майном ЗС України, яка відповідає завданням квартирно-експлуатаційного забезпечення;

може функціонувати автономно або в складі комп'ютерної мережі.

В автономному режимі роботи IA APM розв'язує окремі функціональні завдання і не може оперативно використовувати всю базу щодо об'єктів нерухомості, а обмін інформацією між IA АРM виконується за допомогою електронних носіїв або пересиланням файлів.

Робота в комп'ютерній мережі дає змогу організувати обмін даними по каналах зв'язку, об'єднати інформаційне середовище об'єкта управління i організувати доступ до нього будь-якого начальника (командира) в межах його повноважень;

максимально наближеним до сучасних систем управління нерухомим військовим майном провідних країни світу; 
інтероперабельним і готовим до підключення нових інформаційних ресурсів і розширення кола користувачів підсистеми;

інтегрованим із загальним операційним середовищем Єдиної системи управління адміністративно-господарськими процесами 3С України та перспективною єдиною інформаційною системою управління оборонними ресурсами (DRMIS).

Технічна інфраструктура має використовувати розгорнуту структуровану кабельну мережу та існуючі захищені серверні комплекси і робочі місця для адміністраторів підсистеми, бази даних і безпеки інформації.

Технічним засобам потрібно мати характеристики, що забезпечують функціонування загального, спеціального програмного забезпечення та комплексу засобів захисту.

9. Вимоги до захисту інформаиї в $\underline{I A A P M}$ мають забезпечувати:

гарантований захист інформації від несанкціонованого доступу;

реалізацію розмежування доступу користувачів різних ланок управління до бази даних як по вертикалі, так і по горизонталі згідно визначених ролей і повноважень;

багаторівневий захист інформації, захищеність від кібератак противника на комп'ютерну мережу;

безпеку інформації під час іï обробки та передачі каналами зв'язку відповідно до діючого законодавства.

Для захисту інформації в IA АРM має бути розроблена (або використана існуюча) комплексна система захисту інформації (далі - КСЗІ).

10. Вимоги

забезпечення. Програмне забезпечення IA АРМ має складається із загального та спеціального програмного забезпечення.

До складу загального програмного забезпечення системи мають входити:

операційні системи Windows серверні та на кожній робочій станції;

офісні застосування Microsoft Office на кожній робочій станції.

Спеціальне програмне забезпечення, на якому розгортається IA APM, має забезпечувати функціональність на існуючій платформі загального програмного забезпечення.
Для підвищення ефективності управління нерухомим військовим майном мають використовуватися геоінформаційні технології для створення на карті місцевості картини загальної обстановки (з необхідною деталізацією): простору, розташування, приналежності об'єктів нерухомості, розміщення матеріальних ресурсів для квартирно-експлуатаційного забезпечення.

Для зручності роботи користувачів IA APM необхідно передбачити, щоб загальне спеціалізоване операційне середовище не тільки виконувало закладені функції в головному і допоміжних меню 3 управління процесами квартирно-експлуатаційного забезпечення, а й давало можливість використовувати, браузери, пошукові програми та електронну пошту. У його межах мають забезпечуватися виконання i надання таких функцій та послуг, як отримання i обробка повідомлень, управління функціонуванням робочих станцій, встановлення параметрів взаємодії користувача 3 комп'ютером. Програмнотехнічна платформа має забезпечити роботу систем управління базами даних, сервісу відображення інформації, процесів обробки файлів (завантаження-вивантаження) та можливості вдосконалення конфігурації обладнання, здійснення захисту інформації тощо.

Інформаційна сумісність різних систем $\mathrm{i}$ додатків має забезпечити загальний доступ до даних і спільну з ними роботу (наприклад, їх копіювання, вирізку, вставку з однієї програми в іншу) та одночасне використання можливостей декількох різних автоматизованих інформаційних систем.

Урахування загальних вимог (під час розроблення експериментального діючого макету IA APM керівного складу за напрямом управління нерухомим військовим майном ЗС України) дало змогу виділити та сформувати детальний зміст часткових вимог до конкретного зразка (табл. 1.).

Слід зазначити, що наведені вимоги до IA APM керівного складу за напрямом управління нерухомим військовим майном, у разі прийняття рішення щодо його розроблення, можуть розширюватися та уточнюватися на передпроектній стадії. 
Часткові вимоги до експериментального макету IA АРM

\begin{tabular}{|c|c|}
\hline Вимога & 3міст \\
\hline $\begin{array}{l}\text { аження } \\
\text { (ія даних }\end{array}$ & $\begin{array}{l}\text { Можливість імпорту даних із підсистем управління оборонними ресурсами } \\
\text { (“Майно”, “Житло” тощо). } \\
\text { Можливість імпорту даних з офісних пакетів, таких як Microsoft Office (Oper } \\
\text { Office) тощо. } \\
\text { Можливість автоматичної перевірки введених даних на предмет їх коректност } \\
\text { за алгоритмом, який визначений розробником. } \\
\text { Можливість запобігання дублюванню даних за алгоритмом який визначений } \\
\text { розробником. }\end{array}$ \\
\hline $\begin{array}{c}\text { Обробка } \\
\text { і зберігання даних }\end{array}$ & $\begin{array}{l}\text { Накопичення статистичних даних за бізнес-процесами, які реалізовані в АРМ. } \\
\text { Підтримка цілісності даних. } \\
\text { Використання асоціативної моделі зберігання даних. } \\
\text { Можливість статистичної обробки даних }\end{array}$ \\
\hline $\begin{array}{c}\text { Формування } \\
\text { звітної } \\
\text { документації }\end{array}$ & 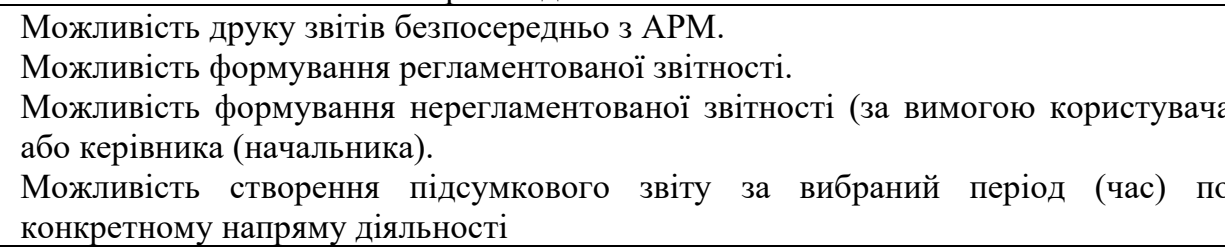 \\
\hline Моніторинг & $\begin{array}{l}\text { Систематичний збір та обробка інформації, яка використовується для } \\
\text { вдосконалення процесу прийняття рішення щодо управління нерухомим } \\
\text { військовим майном. } \\
\text { Спостереження за станом об'єктів квартирно-експлуатаційного забезпечення для } \\
\text { визначення та прогнозування моменту переходу за визначені межі. } \\
\text { Прогнозування варіантів розвитку. } \\
\text { Аналіз діяльності системи квартирно-експлуатаційного забезпечення відповідно } \\
\text { до законодавчої і нормативної бази. } \\
\text { Можливість налаштування вагових коефіцієнтів для моделі оцінки } \\
\text { функціонування системи квартирно-експлуатаційного забезпечення. } \\
\text { Можливість пошуку прихованих закономірностей з використанням методів } \\
\text { інтелектуального аналізу даних }\end{array}$ \\
\hline & $\begin{array}{l}\text { Можливість представлення даних у вигляді, який забезпечує найефективнішу } \\
\text { роботу командира (начальника) щодо їх вивчення }\end{array}$ \\
\hline $\begin{array}{r}\text { Адміні } \\
\text { си }\end{array}$ & $\begin{array}{l}\text { Використання однієї з моделей розмежування прав доступу користувачів дс } \\
\text { ІА АРМ. } \\
\text { Експорт даних у зовнішні програми обробки і аналізу статистичної інформації } \\
\text { Шифрування даних. } \\
\text { Захист даних від несанкціонованого доступу. } \\
\text { Створення і редагуванн інформації про користувачів IA АРМ. } \\
\text { Можливості регулярного створення резервних копій даних }\end{array}$ \\
\hline
\end{tabular}

Для формування вимог до інформаційноаналітичних систем (IAC) використовуються найпоширеніші методи $[3,4]$, а саме: метод, заснований на безлічі опорних поглядів;

метод сценаріїв;

етнографічний метод.

Як правило, не існує універсального підходу до формування та аналізу вимог. Зазвичай для розроблення вимог одночасно використовується декілька підходів.

Водночас, в Україні використовується нормативний документ зі стандартизації Методичні вказівки (Комплекс стандартів і керівних документів на автоматизовані системи) “Автоматизовані системи. Вимоги до змісту документів” - РД 50-34.698-90.
Крім того, під час створення IA AРM необхідно врахувати стандарти НАТО щодо побудови та розвитку комунікаційних та інформаційних систем, зокрема:

принципи побудови на основі сервісорієнтованої архітектури 3 урахуванням C3 Taxonomy Baseline 2.0;

принципи інтеграції, що передбачені стандартом AJP-6 (STANAG 2525);

вимоги до інтероперабельності, що встановлені ADATP-34 (STANAG 5524);

основні правила підтримки життєвого циклу інформаційних систем 3 урахуванням принципів CALS.

Отже, кінцевою метою виконання вимог $\epsilon$ створення єдиного, адаптивного, повністю (або частково) синхронізованого 3 інформаційною системою управління 
оборонними ресурсами IA AРM керівного складу, яке виконуватиме завдання управління нерухомим військовим майном як в мирний час, так і в особливий період.

Висновки. Таким чином, сформовані та обгрунтовані вимоги до IA АРM керівного складу за напрямом управління нерухомим військовим майном Збройних Сил України дадуть змогу забезпечити якісне та своєчасне розроблення його дослідного зразка.

3 використанням сформованих вимог був розроблений експериментальний діючий макет, презентація якого продемонструвала можливості запропонованого інструментарію та підтвердила необхідність розроблення і використання IA APM, що буде вагомим підгрунтям для прийняття раціональних рішень щодо управління нерухомим військовим майном.

Подальші дослідження доцільно зосередити на детальному вивченні шляхів завантаження даних (використання інкрементального завантаження) за об'єкти нерухомості до IA AРM керівного складу ЗС України.

\section{СПИСОК ВИКОРИСТАНОЇ ЛІТЕРАТУРИ}

1. Галаган В. I., Бондарчук С. В. Полішко С. В. Застосування систем підтримки прийняття рішень в управлінні нерухомим військовим майном Збройних Сил України - К : ЗНП ЦВСД НУОУ, випуск № 2 (63), 2018.

2. ГОСТ 34.601-90 Стадії створення [Електроний ресурс] - Режим доступу: http://docs.cntd.ru/document/gost-34601-90.

3. Бредун П. О. Архитектура корпоративного интегрированного информационного пространства информационной системы управления документооборотом / П. О. Бредун, Л. Г. Данилова, И. П. Иванов "Интеллект\&ИТ Бизнес Металл" - М., 2004. - С. 43-46.

4. Абдикеев Я. М. Автоматизированные информационные системы в производстве, маркетинге и финансах: учеб. пособие / Я. М. Абдикеев; под общ. ред. К. И. Курбакова. - М.: КОС ИНФ, Рос. экон. акад. 2003. $-148 \mathrm{c}$.

Стаття надійшла до редакційної колегії 06.02.2019

Галаган В. И., к.воен.н., доцент;

Полишко С. В., к.т.н., с.н.с.;

Бондарчук С. В.

Центр военно-стратегических исследований Национального университета обороны Украины имени Ивана Черняховского, Киев

Формирование требований к информационно-аналитическому автоматизированному рабочему месту руководящего состава по направлению управления недвижимым военным имуществом Вооруженных Сил Украины

Резюме. Статья посвящена вопросам формирования и обоснования требований к построению информационноаналитического автоматизированного рабочего места руководящего состава по направлению управления недвижимым военным имуществом, как одной из важнейших составляющих жизненного цикла информационных систем, используемых в повседневной деятельности организаций (структур) Вооруженных Сил Украины.

Ключевые слова: информационно-аналитическое автоматизированное рабочее место; автоматизированное рабочее место руководящего состава; управления недвижимым военным имуществом.

V. Galagan, Ph.D (Military), assistant professor;

S. Polishko, Ph.D (Technical), senior researcher;

S. Bondarchuk

Center for Military and Strategic Studies National Defence University of Ukraine named after Ivan Cherniakhovskyi, Kyiv

Formation of requirements for information-analytical automated workplace of the management team in the direction of the management of immovable military property of the Armed Forces of Ukraine

Resume. The article is devoted to the formation and justification of requirements for the construction of an informationanalytical automated workplace for senior management in the direction of real estate military property management, as one of the most important components of the life cycle of information systems used in the daily activities of organizations (structures) of the Armed Forces of Ukraine.

Keywords: an informational-analytical automated workplace; an automated workplace of the governing staff; and the management of immovable military property. 